\title{
The Stability of The Financial System: a Comparison of Developed and Less Developed Countries
}

\author{
http://doi.org/10.21272/fmir.5(2).5-13.2021
}

Halil D. Kaya, ORCID: https://orcid.org/0000-0002-7535-9857

Professor of Finance, Department of Accounting and Finance, College of Business and Technology, Northeastern State University, USA

\begin{abstract}
In this study, we examine the relationship between the development level of a country and stability of its financial system. We look at seven measures of stability. These are Bank z-score, Bank non-performing loans to gross loans, Bank capital to total assets, Bank credit to bank deposits, Regulatory capital to risk-weighted assets, Liquid assets to deposits and short term funding, and Provisions to non-performing loans. First, we compare developed and less developed countries' stability measures. Do developed countries have more stable financial systems than less developed countries or is the opposite true? When we compare high-income countries to low- and middle-income countries, we find that low- and middle-income countries have better "stability" values in five measures. For the other two measures, we do not find any significant difference between the two groups. Then, we look at how high-income OECD countries differ from high-income nonOECD countries in terms of their financial system's stability. When we compare high-income OECD-member countries to high-income Non-OECD-member countries, we find that high-income Non-OECD-member countries have better "stability" values in four measures. For the other three measures, we do not find any significant difference between the two groups. We conclude that developed countries, especially OECD members, are under greater risk when facing an economic/financial crisis.
\end{abstract}

Keywords: stability, financial system, OECD, income level, developed countries.

JEL Classification: G01, G10, G20, G21, G32.

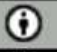

This work is licensed under a Creative Commons Attribution 4.0 International License

Cite as: Kaya, H.D. (2021). The Stability of The Financial System: a Comparison of Developed and Less Developed Countries. Financial Markets, Institutions and Risks, 5(2), 513. http://doi.org/10.21272/fmir.5(2).5-13.2021

Received: 1 March, 2021

Accepted: 31 March, 2021

Published: 25 June, 2021

Copyright: (C) 2021 by the author. Licensee Sumy State University, Ukraine. This article is an open access article distributed under the terms and conditions of the Creative Commons Attribution (CC BY) license (https://creativecommons.org/licenses/by/4.0/)

\section{Introduction}

In this study, we examine the relationship between the development level of a country and the stability of its financial system. We use World Bank's Global Financial Development Database (GFDD) which have data on 203 countries. This database includes seven measures for stability. These are Bank z-score, Bank nonperforming loans to gross loans, Bank capital to total assets, Bank credit to bank deposits, Regulatory capital to risk-weighted assets, Liquid assets to deposits and short term funding, and Provisions to non-performing loans. First, we examine whether OECD membership affects stability. For this purpose, we compare the measures of high-income OECD-member countries and high-income non-OECD-member countries. Then, we examine how development level itself affects stability. To achieve that objective, we compare the measures of high-income countries to those of low- and middle-income countries.

The previous studies use different measures for "stability". These studies focus on different variables like exchange rates, interest rates, the central bank's reserves, the drop in GDP, the decline in the stock market, or a combination of these measures. For example, Edwards (1989), Bruggemann and Linne (1999), Frankel and Rose (1996), and Osband and Rijckeghem (2000) focus on nominal exchange rates mainly against the U.S. dollar. Apoteker and Barthelemy (2000) and Goldfajn and Valdes (1998) focus on real exchange rates. Sachs, Tornell and Velasco (1996), Fratzcher (1998), Corsetti, et al (1998), Kaminsky et al. (1998), Bussiere and 
Mulder (1999, 2000), Berg and Pattillo (1999), and Tornell (1999) combine exchange rates with changes in reserves and use this combination as an indicator. Meanwhile, other papers like Herrera and Garcia (1999), Eichengreen, Rose and Wyplosz (1995), and Hawkins and Klau (2000) combine changes in interest rates, reserves, and the exchange rate, and use this as an indicator.

In this paper, we look from a different perspective and focus on "banks' stability". We believe that these "bank stability" measures (i.e. Bank z-score, Bank non-performing loans to gross loans, Bank capital to total assets, Bank credit to bank deposits, Regulatory capital to risk-weighted assets, Liquid assets to deposits and short term funding, and Provisions to non-performing loans) are more direct measures of "financial system stability", therefore we argue that the conclusions drawn here will better represent the stability of the financial system.

As mentioned above, in this study, we examine how developed countries and less developed countries differ in terms of "stability". We also examine whether there is a significant difference between high-income OECD members and high-income non-OECD members. These two groups of countries have different cultures. They also differ in terms of resources and infrastructure. The comparison of these two groups of countries in this study will shed a new light on how these factors (i.e. mainly culture, resources and infrastructure) affect the vulnerability of their financial systems. We are hoping that our findings will guide policymakers by showing them which group of countries are more vulnerable to a sudden shock that is caused by an economic/financial crisis.

The paper proceeds as follows: Section 1 discusses the previous literature; Section 2 states the hypotheses; Section 3 describes the data and the methodology; Section 4 shows the results of the empirical tests; and Section 5 concludes.

\section{Literature Review}

Previous papers examine different measures of stability. While some of them focus on the changes in the exchange rates and interest rates, others focus on the central bank reserves, the GDP, the stock market, or a combination of these measures. Bruggemann and Linne (1999), Edwards (1989), Frankel and Rose (1996), and Osband and Rijckeghem (2000) examine the changes in nominal exchange rates (mainly against the U.S. dollar) while Apoteker and Barthelemy (2000) and Goldfajn and Valdes (1998) focus on real exchange rates. Rose and Spiegel (2012), on the other hand, examine the changes in the SDR exchange rate.

Several other papers focus on a combination of different measures. Herrera and Garcia (1999), Eichengreen, Rose and Wyplosz (1995), and Hawkins and Klau (2000) examine a measure that combines changes in interest rates, the exchange rate and the reserves. Fratzcher (1998), Sachs, Tornell and Velasco (1996), Corsetti, et al (1998), Bussiere and Mulder (1999, 2000), Kaminsky et al. (1998), Berg and Pattillo (1999), and Tornell (1999) focus on a measure that is combination of exchange rates and changes in reserves. Yet other papers analyze the drop in GDP (Ghosh and Ghosh 2003) and equity market changes (Grier and Grier 2001).

Hawkins and Klau (2000), Kaminsky et al (1998) and Abiad (2003) do reviews of the literature to determine the most commonly used measures. Frankel and Saravelos (2010) integrate the findings of these reviews and provides a more systematic analysis of the indicators in the studies cited by Abiad (2003). Their paper explains that past movements in the real exchange rate and the central bank reserves have proven the most useful in explaining crises.

Frankel and Saravelos (2010) show use six different variables to measure the 2008-2009 crisis. These are stock market performance, drops in GDP and industrial production, reserve losses, currency depreciation, and participation in an IMF program. They explain that the real exchange rate, GDP, foreign exchange reserves, the growth rate of credit, and the current account are the most common significant indicators found in the previous literature. They especially show reserves and the real exchange rate as the two most commonly found indicators of a crisis.

Obstfeld, Shambaugh and Taylor $(2009,2010)$ use the percentage depreciation of local currencies against the US dollar as a proxy of the crisis. Rose and Spiegel (2012) use a model that combines the changes in real GDP, country credit ratings, the stock market, and the exchange rate to predict the crisis. Jara, Moreno and Tovar (2009) argue that although Latin America was negatively affected during the 2008 crisis, the impact was less severe than the impact during the previous crises. Jara, Moreno and Tovar (2009) contend that policy responses across the region were significant, and in many cases pre-emptive. According to the authors central banks tried 
to provide foreign currency liquidity to the private sector in order to ensure both the continued availability of external financing and the continued operation of foreign exchange markets.

Berkmen et al. (2009) focus on the 2008 crisis and look at the change in growth forecasts by professional economists before and after the crisis. They show that countries with more rapid credit growth and more leveraged domestic financial systems had suffered larger downward revisions.

Lane and Milesi-Ferretti (2011) find that the countries that suffered most in 2008-2009 were those that had previously shown higher current account deficits, pre-crisis growth trade openness and share of manufacturing. The authors also show that high-income countries were hit more than low-income countries (the opposite of what was seen during previous global shocks). Dominguez, Hashimoto and Ito (2011) and Llaudes, Salman and Chivakul (2011) support this by showing that emerging market countries that had accumulated reserves earlier suffered lower output declines in the global recession.

Han and Melecky (2013) find that greater access to bank deposits can make the deposit funding base of banks more resilient in times of financial stress. According to the authors, broader access to bank deposits is important for financial stability.

\section{Hypotheses}

We expect high-income countries' financial systems to be less stable than those of other countries. Due to the reasons explained above, we also expect high-income OECD member countries' financial systems to be less stable than those of non-OECD member countries.

Therefore, our formal hypotheses are as follows:

Hypothesis 1: High-income countries' financial systems are less stable compared to other countries' financial systems.

Hypothesis 2: High-income OECD member countries' financial systems are less stable compared to highincome non-OECD member countries' financial systems.

Table 1-Panel A shows that, for some of the stability measures, we expect the High-Income OECD countries to have higher values, while for others, we expect the High-Income Non-OECD countries to have higher values.

Similarly, Panel B shows that, for some of the stability measures, we expect the High-Income countries (including the Non-OECD countries) to have higher values, while for others, we expect "Other" countries to have higher values. In the next section, we explain all of the variables in detail.

Table 1. The Expected Results of the Comparisons

\begin{tabular}{|c|c|c|}
\hline \multicolumn{3}{|c|}{ Panel A. High-Income OECD vs High-Income Non-OECD } \\
\hline Variable & OECD & Non-OECD \\
\hline Bank Z-score & & $\mathrm{X}$ \\
\hline Bank non-performing loans to gross loans (\%) & $\mathrm{X}$ & \\
\hline Bank capital to total assets $(\%)$ & & $\mathrm{X}$ \\
\hline Bank credit to bank deposits (\%) & $\mathrm{X}$ & \\
\hline Regulatory capital to risk-weighted assets (\%) & & $\mathrm{X}$ \\
\hline Liquid assets to deposits and short term funding (\%) & & $\mathrm{X}$ \\
\hline Provisions to non-performing loans (\%) & & $\mathrm{X}$ \\
\hline \multicolumn{3}{|l|}{ Panel B. High-Income vs Other } \\
\hline Variable & High-Income & Other \\
\hline Bank Z-score & & $\mathrm{X}$ \\
\hline Bank non-performing loans to gross loans (\%) & $\mathrm{X}$ & \\
\hline Bank capital to total assets $(\%)$ & & $\mathrm{X}$ \\
\hline Bank credit to bank deposits (\%) & $\mathrm{X}$ & \\
\hline Regulatory capital to risk-weighted assets (\%) & & $\mathrm{X}$ \\
\hline Liquid assets to deposits and short term funding (\%) & & $\mathrm{X}$ \\
\hline Provisions to non-performing loans $(\%)$ & & $\mathrm{X}$ \\
\hline
\end{tabular}

Source: Author's own work.

\section{Data and Methodology}

In this study, as measures of stability, we use seven variables. These are listed below with their sources explained in parenthesis. We actually collected the data from World Bank's Global Financial Development 
Database (GFDD) which has information on access to finance, and depth, efficiency, and stability of financial systems in the world. World Bank collected these data from different sources. All of the variables and their definitions are taken from World Bank's Global Financial Development Database.

Below are the "stability" measures that we are using in this study:

Bank Z-score

Bank non-performing loans to gross loans (\%)

Bank capital to total assets (\%)

Bank credit to bank deposits (\%)

Regulatory capital to risk-weighted assets (\%)

Liquid assets to deposits and short term funding (\%)

Provisions to non-performing loans (\%)

Out of the 203 countries in the sample, 31 countries are High-Income OECD countries, 29 countries are HighIncome Non-OECD countries, 108 countries are Middle-Income countries, and 35 countries are Low-Income countries.

In order to compare the High-Income countries to the Other countries and also to compare the High-Income OECD countries to the High-Income Non-OECD countries, we use the Mann-Whitney-Wilcoxon test in the following section.

In the next section, we show the summary statistics for each group (i.e. High-Income OECD, High-Income Non-OECD, Middle-Income, and Low-Income countries). We also show the results of our empirical tests (i.e. Mann-Whitney-Wilcoxon test) that compare the stability measures of the High-Income OECD countries and the High-Income Non-OECD countries, and also the measures of the High-Income OECD countries and the Middle- and Low-Income countries.

\section{Empirical Results}

Table 2-Panel A shows the summary statistics for the High-Income OECD Countries. Table 2-Panel B shows the summary statistics for the High-Income Non-OECD Countries. We are seeing that, in four measures (i.e. "Bank non-performing loans to gross loans (\%)", "Bank credit to bank deposits (\%)", "Liquid assets to deposits and short term funding (\%)", and "Provisions to non-performing loans (\%)"), the High-Income OECD countries have higher values compared to the High-Income Non-OECD countries.

In terms of the other three measures (i.e. "Bank Z-score", "Bank capital to total assets (\%)", and "Regulatory capital to risk-weighted assets (\%)"), the High-Income Non-OECD countries have higher values.

Table 2. Stability of the Financial System in High-Income Countries

\begin{tabular}{|c|c|c|c|c|}
\hline \multicolumn{5}{|l|}{ Panel A. High-Income OECD Countries } \\
\hline Variable & Mean & StD & Min. & Max. \\
\hline Bank Z-score & 13.45 & 8.17 & -3.45 & 33.35 \\
\hline Bank non-performing loans to gross loans (\%) & 6.48 & 7.76 & 0.40 & 38.80 \\
\hline Bank capital to total assets $(\%)$ & 6.68 & 2.01 & 4.30 & 11.20 \\
\hline Bank credit to bank deposits (\%) & 119.88 & 36.74 & 47.29 & 198.20 \\
\hline Regulatory capital to risk-weighted assets (\%) & 14.89 & 3.24 & 9.30 & 24.00 \\
\hline Liquid assets to deposits and short term funding (\%) & 37.55 & 26.41 & 9.51 & 133.78 \\
\hline Provisions to non-performing loans (\%) & 44.95 & 16.61 & 2.50 & 71.40 \\
\hline \multicolumn{5}{|l|}{ Panel B. High-Income Non-OECD Countries } \\
\hline Variable & Mean & StD & Min. & Max. \\
\hline Bank Z-score & 17.90 & 9.54 & 0.83 & 45.83 \\
\hline Bank non-performing loans to gross loans (\%) & 5.39 & 4.13 & 0.70 & 12.30 \\
\hline Bank capital to total assets $(\%)$ & 11.09 & 3.33 & 6.90 & 17.20 \\
\hline Bank credit to bank deposits (\%) & 92.44 & 23.69 & 49.94 & 133.80 \\
\hline Regulatory capital to risk-weighted assets (\%) & 16.55 & 2.67 & 12.80 & 21.20 \\
\hline Liquid assets to deposits and short term funding (\%) & 25.98 & 13.47 & 11.78 & 68.90 \\
\hline Provisions to non-performing loans (\%) & 41.50 & 20.06 & 11.50 & 67.80 \\
\hline
\end{tabular}


Source: Author's own work.

Table 3 shows the results of the Mann-Whitney-Wilcoxon tests that compare the "stability" variables in HighIncome OECD countries and the High-Income Non-OECD countries. We expect High-Income Non-OECD countries to have more stable financial systems compared to High-Income OECD countries. By design, we expect High-Income Non-OECD countries to have higher values for some of these variables and lower values for the other variables. Table 1 has summarized our expectations.

Table 3. Stability of the Fin. System in High-Income OECD vs. Non-OECD Countries

\begin{tabular}{|l|c|c|c|c|}
\hline \multicolumn{1}{|c|}{ Variable } & OECD & Non-OECD & p-value & Expected? \\
\hline Bank Z-score & 13.45 & $\mathbf{1 7 . 9 0}$ & 0.0353 & YES \\
\hline Bank non-performing loans to gross loans (\%) & 6.48 & 5.39 & 0.4830 & \\
\hline Bank capital to total assets (\%) & 6.68 & $\mathbf{1 1 . 0 9}$ & 0.0004 & YES \\
\hline Bank credit to bank deposits (\%) & $\mathbf{1 1 9 . 8 8}$ & 92.44 & 0.0037 & YES \\
\hline Regulatory capital to risk-weighted assets (\%) & 14.89 & $\mathbf{1 6 . 5 5}$ & 0.0469 & YES \\
\hline Liquid assets to deposits and short term funding (\%) & 37.55 & 25.98 & 0.1193 & \\
\hline Provisions to non-performing loans (\%) & 44.95 & 41.50 & 0.3482 & \\
\hline
\end{tabular}

Source: Author's own work.

Table 3 shows that, as expected, High-Income Non-OECD countries have significantly higher values in terms of "Bank Z-score". Having higher values in this measures means that the financial systems of High-Income Non-OECD countries are more stable than the financial systems of High-Income OECD countries. While the mean value of "Bank Z-score" is 13.45 for High-Income OECD countries, the corresponding value is 17.90 for High-Income Non-OECD countries ( $\mathrm{p}$-value of the difference $=0.0353$ ).

In terms of "Bank non-performing loans to gross loans (\%)", we expect High-Income OECD countries to have higher values. But, the table shows that there is no significant difference between the two groups in terms of this measure. While the mean value of this measure is $6.48 \%$ for High-Income OECD countries, the corresponding value is $5.39 \%$ for High-income Non-OECD countries ( $p$-value of the difference $=0.4830$ ).

In terms of "Bank capital to total assets (\%)", we expect High-Income Non-OECD countries to have higher values. As expected, we are seeing that the mean value of this measure is $6.68 \%$ for High-Income OECD countries while the corresponding value is $11.09 \%$ for High-Income Non-OECD countries ( $\mathrm{p}$-value of the difference $=0.0004)$.

In terms of "Bank credit to bank deposits (\%)", we expect High-Income OECD countries to have higher values. As expected, we are seeing that the mean value of this measure is $119.88 \%$ for High-Income OECD countries while the corresponding value is $92.44 \%$ for High-Income Non-OECD countries (p-value of the difference $=0.0037$ ).

In terms of "Regulatory capital to risk-weighted assets (\%)", we expect High-Income Non-OECD countries to have higher values. As expected, we are seeing that the mean value of this measure is $14.89 \%$ for High-Income OECD countries while the corresponding value is $16.55 \%$ for High-Income Non-OECD countries ( $p$-value of the difference $=0.0469$ ).

When we look at "Liquid assets to deposits and short term funding (\%)", we expect High-Income Non-OECD countries to have higher values. We are seeing that there is no statistically significant difference between the two groups in terms of this measure. While the mean value of this measure is $37.55 \%$ for High-Income OECD countries, the corresponding value is $25.98 \%$ for High-Income Non-OECD countries (p-value of the difference $=0.1193$ ).

Finally, when we look at "Provisions to non-performing loans (\%)", we expect High-Income Non-OECD countries to have higher values. We are seeing that there is no statistically significant difference between the two groups in terms of this measure. While the mean value of this measure is $44.95 \%$ for High-Income OECD countries, the corresponding value is $41.50 \%$ for High-Income Non-OECD countries (p-value of the difference $=0.3482$ ).

To summarize, the results of the comparisons between High-Income OECD countries and High-Income NonOECD countries are mostly in line with our expectations. For four of these variables, we find that, HighIncome Non-OECD countries have better "stability" measures. For the other three measures, we do not find any significant difference between the two groups. 
Table 4-Panel A shows the summary statistics for the Low-Income Countries. Table 4-Panel B shows the summary statistics for the Middle-Income Countries.

Table 4. Stability of the Financial System in Low- and Middle-Income Countries

\begin{tabular}{|c|c|c|c|c|}
\hline \multicolumn{5}{|l|}{ Panel A. Low-Income Countries } \\
\hline Variable & Mean & StD & Min. & Max. \\
\hline Bank Z-score & 10.91 & 7.54 & 1.06 & 30.39 \\
\hline Bank non-performing loans to gross loans (\%) & 8.20 & 5.45 & 2.20 & 15.10 \\
\hline Bank capital to total assets $(\%)$ & 15.40 & 4.65 & 9.00 & 21.60 \\
\hline Bank credit to bank deposits (\%) & 67.97 & 25.32 & 15.20 & 119.36 \\
\hline Regulatory capital to risk-weighted assets (\%) & 23.80 & 4.88 & 17.10 & 30.30 \\
\hline Liquid assets to deposits and short term funding (\%) & 39.84 & 17.72 & 18.76 & 94.01 \\
\hline Provisions to non-performing loans (\%) & 53.72 & 6.18 & 45.70 & 61.60 \\
\hline \multicolumn{5}{|l|}{ Panel B. Middle-Income Countries } \\
\hline Variable & Mean & StD & Min. & Max. \\
\hline Bank Z-score & 16.56 & 11.60 & 0.14 & 62.14 \\
\hline Bank non-performing loans to gross loans (\%) & 6.61 & 6.29 & 0.70 & 30.80 \\
\hline Bank capital to total assets $(\%)$ & 10.62 & 2.97 & 3.90 & 17.90 \\
\hline Bank credit to bank deposits (\%) & 95.89 & 90.99 & 21.19 & 898.01 \\
\hline Regulatory capital to risk-weighted assets (\%) & 16.65 & 3.60 & 9.90 & 30.40 \\
\hline Liquid assets to deposits and short term funding (\%) & 33.79 & 18.83 & 5.25 & 125.16 \\
\hline Provisions to non-performing loans (\%) & 102.27 & 59.17 & 32.00 & 278.10 \\
\hline
\end{tabular}

Source: Author's own work.

Next, we want to examine the relation between countries' income levels and the stability of their financial systems. In order to do this, we compare High-Income countries to Middle- and Low-Income countries. Table 5 shows the results of the Mann-Whitney-Wilcoxon tests that compare the "stability" variables in High-Income countries (i.e. including OECD and Non-OECD countries) and Other countries (which includes Low- and Middle-Income Countries). We expect Low- and Middle-Income countries to have more stable financial systems compared to High-Income countries. By design, we expect High-Income countries to have higher values for some of these variables and lower values for the other variables. Table 1 has summarized our expectations.

Table 5. Stability of the Financial System in High-Income vs. Other Countries

\begin{tabular}{|c|c|c|c|c|}
\hline Variable & $\begin{array}{c}\text { High- } \\
\text { Income }\end{array}$ & Other & p-value & Expected? \\
\hline Bank Z-score & 15.24 & 15.22 & 0.2051 & \\
\hline Bank non-performing loans to gross loans (\%) & 6.25 & 6.79 & 0.2867 & \\
\hline Bank capital to total assets $(\%)$ & 7.75 & 11.09 & $<0.0001$ & YES \\
\hline Bank credit to bank deposits (\%) & 107.53 & 89.59 & $<0.0001$ & YES \\
\hline Regulatory capital to risk-weighted assets (\%) & 15.26 & $\mathbf{1 7 . 4 7}$ & 0.0044 & YES \\
\hline Liquid assets to deposits and short term funding (\%) & 33.61 & 35.11 & 0.0993 & YES \\
\hline Provisions to non-performing loans $(\%)$ & 44.28 & 97.34 & $<0.0001$ & YES \\
\hline
\end{tabular}

Source: Author's own work.

Table 5 shows that, in terms of "Bank Z-score" and "Bank non-performing loans to gross loans (\%)", there is no significant difference between the two groups. While the mean value of "Bank Z-score" is 15.24 for HighIncome countries, the corresponding value is 15.22 for Other countries ( $p$-value of the difference $=0.2051$ ). Similarly, while the mean value of "Bank non-performing loans to gross loans (\%)" is 6.25 for High-Income countries, the corresponding value is $6.79 \%$ for Other countries ( $\mathrm{p}$-value of the difference $=0.2867$ ).

In terms of "Bank capital to total assets (\%)", we expect Other countries to have higher values. As expected, we are seeing that the mean value of this measure is $7.75 \%$ for High-Income countries while the corresponding value is $11.09 \%$ for Other countries ( $p$-value of the difference $<0.0001$ ).

In terms of "Bank credit to bank deposits (\%)", we expect High-Income countries to have higher values. As expected, we are seeing that the mean value of this measure is $107.53 \%$ for High-Income countries while the corresponding value is $89.59 \%$ for Other countries ( $p$-value of the difference $<0.0001$ ). 
In terms of "Regulatory capital to risk-weighted assets (\%)", we expect Other countries to have higher values. As expected, we are seeing that the mean value of this measure is $15.26 \%$ for High-Income countries while the corresponding value is $17.47 \%$ for Other countries ( $p$-value of the difference $=0.0044$ ).

When we look at "Liquid assets to deposits and short term funding (\%)", we expect Other countries to have higher values. As expected, we are seeing that the mean value of this measure is $33.61 \%$ for High-Income countries while the corresponding value is $35.11 \%$ for Other countries ( $\mathrm{p}$-value of the difference $=0.0993$ ).

Finally, when we look at "Provisions to non-performing loans (\%)", we expect Other countries to have higher values. As expected, we are seeing that the mean value of this measure is $44.28 \%$ for High-Income countries while the corresponding value is $97.34 \%$ for Other countries ( $p$-value of the difference $<0.0001$ ).

To summarize, the results of the comparisons between High-Income countries and Other countries are mostly in line with our expectations. For five of these variables, we find that, Other countries have better "stability" measures. For the other two measures, we do not find any significant difference between the two groups.

\section{Conclusion}

In this study, we examine two issues. First, we look at the relation between countries' income levels and the stability of their financial system. Do richer countries have more stable financial systems when compared to other countries or is the opposite true? Then, we look at how OECD membership affects the stability of a country's financial system.

We look into seven measures of efficiency. These measures are "Bank Z-score", "Bank non-performing loans to gross loans (\%)", "Bank capital to total assets (\%)", "Bank credit to bank deposits (\%)", "Regulatory capital to risk-weighted assets (\%)", "Liquid assets to deposits and short term funding (\%)", and "Provisions to nonperforming loans (\%)". The data on these variables are collected from World Bank's Global Financial Development Database (GFDD).

The results of our comparisons between High-Income OECD countries and High-Income Non-OECD countries are mostly in line with our expectations. For four of these variables, we find that, High-Income NonOECD countries have better "stability" measures. These are "Bank Z-score", "Bank capital to total assets (\%)", "Bank credit to bank deposits (\%)", and "Regulatory capital to risk-weighted assets (\%)". For the other three measures, we do not find any significant difference between the two groups.

The results of our comparisons between High-Income countries and Other countries are also mostly in line with our expectations. For five of these variables, we find that, "Other countries" have better "stability" measures. These are "Bank capital to total assets (\%)", "Bank credit to bank deposits (\%)", "Regulatory capital to risk-weighted assets (\%)", "Liquid assets to deposits and short term funding (\%)", and "Provisions to nonperforming loans (\%)". For the other two measures, we do not find any significant difference between the two groups.

Our results indicate that policymakers need to consider OECD membership and income level as determinants of a system's "stability". Also, any study that examines the "stability" of a system should control for incomelevel and OECD membership.

\section{References}

1. Abiad, A. (2003). Early Warning Systems: A Survey and a Regime-Switching Approach, IMF Working Papers, 03/32, International Monetary Fund. [Google Scholar]

2. Apoteker, T., Sylvain, B. (2000). Genetic Algorithms and Financial Crises in Emerging Markets, AFFI International Conference in Finance Processing. [Link]

3. Berg, A., Pattillo, C. (1999). Are Currency Crises Predictable? A Test, IMF Staff Papers, 46(2). [Google Scholar]

4. Berkmen, P., Gelos, G., Rennhack, R. and Walsh, J. (2009). The Global Financial Crisis: Explaining CrossCountry Differences in the Output Impact, IMF Working Papers, 09/280, International Monetary Fund. [Google Scholar]

5. Brüggemann, A., Linne, T. (1999). How Good are Leading Indicators for Currency and Banking Crises in Central and Eastern Europe? An Empirical Test, IWH Discussion Papers 95, Halle Institute for Economic Research. [Link] 
6. Bussiere, M., Mulder, C. (1999). External Vulnerability in Emerging Market Economies - How High Liquidity Can Offset Fundamentals and the Effects of Contagion, IMF Working Papers, 99/88, International Monetary Fund. [Google Scholar]

7. Bussiere, M., Mulder, C. (2000). Political Instability and Economic Vulnerability, International Journal of Finance \& Economics, 5(4), 30. [Google Scholar]

8. Corsetti, G., Pesenti, P., and Roubini, N. (1998). Paper Tigers? A Model of the Asian Crisis, Research Paper 9822, Federal Bank of New York. [Link]

9. Dominguez, K., Yukio, H. Takatoshi, I. (2011). International Reserves and the Global Financial Crisis. NBER conference on the Global Financial Crisis, Bretton Woods, June. [Link]

10. Edwards, S. (1989). Real Exchange, Devaluation, and Adjustment: Exchange Rate Policy in Developing Countries (MIT Press Cambridge, MA). [Link]

11. Eichengreen, B., et. al. (1995). Exchange Market Mayhem: The Antecedents and Aftermath of Speculative Attacks, Economic Policy, 10(21), 249-312. [Google Scholar]

12. Frankel, J., and Rose, A. (1996). Currency Crashes in Emerging Markets: An Empirical Treatment, of International Economics, 41, 3(4), 351-366. [Link]

13. Frankel, J., Shang-Jin, W. (2005). Managing Macroeconomic Crises, in Managing Economic Volatility and Crises: A Practitioner's Guide, edited by Joshua Aizenman and Brian Pinto (Cambridge University Press; paperback 2010).[Link]

14. Frankel, J. A., Saravelos, G. (2010). Are leading indicators of financial crises useful for assessing country vulnerability? Evidence from the 2008-09 global crisis. No. w16047. National bureau of economic research.[Link]

15. Fratzscher, M. (1998). Why Are Currency Crises Contagious? A Comparison of the Latin American Crisis of 1994-1995 and the Asian Crisis of 1997-1998, Weltwirtschaftliches Archiv, 134(4), 664-91. [Link]

16. Ghosh, S. R., and Atish, R. G. (2003). Structural Vulnerabilities and Currency Crises, IMF Staff Papers, Palgrave Macmillan Journals, 50(3), 7. [Google Scholar]

17. Goldfajn, I. Valdes, R. O. (1998). Are Currency Crises Predictable? European Economic Review, Elsevier, 42(3-5), 873-885. [Link]

18. Grier, K. Grier, R. (2001). Exchange Rate Regimes and the Cross-Country Distribution of the 1997 Financial Crisis, Economic Inquiry, 39(1), 139-48. [CrossRef]

19. Han, R., Melecky, M. (2013). Financial inclusion for financial stability: access to bank deposits and the growth of deposits in the global financial crisis. [Link]

20. Hawkins, J. Klau, M. (2000). Measuring potential vulnerabilities in emerging market economies, BIS Working Papers 91, Bank for International Settlements. [Google Scholar]

21. Herrera, S., and Conrado, G. (1999). User's Guide to an Early Warning System for Macroeconomic Vulnerability in Latin American Countries, Policy Research Working Paper Series 2233, The World Bank. [Google Scholar]

22. Jara, A., Moreno, R., Tovar, C. E. (2009). The global crisis and Latin America: financial impact and policy responses. [Google Scholar]

23. Kaminsky, G., Saul, L. and Carmen, R. (1998). Leading Indicators of Currency Crisis, IMF Staff Papers, Palgrave Macmillan Journals, 45(1). [Link]

24. Lane, P., Milesi-Ferretti, G. M. (2011). The Cross-Country Incidence of the Global Crisis, IMF Economic Review, 59, 77-110. IMF Working Papers 10/171. [Google Scholar]

25. Llaudes, R., Ferhan, S. and Chivakul, M. (2011). The Impact of the Great Recession on Emerging Markets, IMF Research Bulletin, 12(2). Summary of IMF WP 10/237. [Google Scholar] 
26. Obstfeld, M., Shambaugh, J., Taylor, A. (2009). Financial Instability, Reserves, and Central Bank Swap Lines in the Panic of 2008, American Economic Review, 99(2), May, 480-86. [Link]

27. Obstfeld, M., Shambaugh, J., Taylor, A. (2010). Financial Stability, the Trilemma, and International Reserves. American Economic Journal: Macroeconomics. [Google Scholar]

28. Osband, K., Rijckeghem, C. (2000). Safety from Currency Crashes, IMF Staff Papers, 47(2). [Link]

29. Rose, A., Spiegel, Mark. (2012). Cross-Country Causes and Consequences of the 2008 Crisis: Early Warning, Japan and the World Economy, 24(1), 1-16. [Link]

30. Sachs, J., Tornell, A., Velasco, A. (1996). Financial Crises in Emerging Markets: The Lessons from 1995, Brookings Papers on Economic Activity, 27(1), 147-199. [Link]

31. Tornell, A. (1999). Common Fundamentals in the Tequila and Asian Crises, Harvard Institute of Economic Research Working Papers 1868. [Link] 